\title{
Environmental assessment of MSW collection/transport using biomethane in mid-sized metropolitan areas of developing countries
}

José Carlos Martins Ramalho ( $\nabla$ jc_ramalho@hotmail.com )

Federal University of Espirito Santo: Universidade Federal do Espirito Santo https://orcid.org/00000003-4579-6009

\section{João Luiz Calmon}

Federal University of Espirito Santo: Universidade Federal do Espirito Santo

Diogo Appel Colvero

Federal University of Goiás: Universidade Federal de Goiás

\section{Renato Ribeiro Siman}

Federal University of Espirito Santo: Universidade Federal do Espirito Santo https://orcid.org/00000003-2939-7403

\section{Research Article}

Keywords: Life cycle assessment, waste collection, waste transport, biomethane, developing countries

Posted Date: August 13th, 2021

DOl: https://doi.org/10.21203/rs.3.rs-696225/v1

License: (c) (1) This work is licensed under a Creative Commons Attribution 4.0 International License. Read Full License 


\section{Abstract}

The novelty of this paper is the focus solely on MSW collection/transport in mid-sized metropolitan regions of developing countries, using biomethane (which can be supplied by the MSW management system) an alternative fuel and different waste collection methods. The eight proposed scenarios, compared to the baseline scenario, combine diesel and biowaste, doorto-door and bring collection methods, as well as two different levels of sourceseparated collection. The results have shown if the collection vehicles use biomethane, the impacts will always be significantly lower than using diesel (between 68-98\%, depending on the impact category and scenario), even accounting with the uncertainty of the results. In this particular case-study, increasing source-separated collection also reduced the transport impacts in $40-50 \%$, as the transfer stations are closer to the recycling facilities than the landfills. This is because the fuel consumption of transport is a function of distance, so is the impact. Therefore, this study recommends: using biomethane produced from anaerobic digestion of organic waste instead of diesel to expand circular MSW management; establishing transfer stations for the municipalities located more than $25 \mathrm{~km}$ away from waste management facilities; expanding the collection coverage to $100 \%$; increasing sourceseparated collection and recycling.

\section{Introduction}

In Brazil, municipal solid waste (MSW) management is going through a slow transition process. Specifically, in terms of switching from a linear model to a circular one that diverts waste from landfills, following the waste hierarchy. For instance, the National Plan for Solid Waste Management (Plano Nacional de Resíduos Sólidos - PLANARES), drafted by MMA (2012) has proposed for 2015 a minimum target of $25 \%$ and $30 \%$ for diversions of biowaste and recyclables for landfills, respectively. Unfortunately, the latest PLANARES draft, yet unapproved to the date of this study, planned unambitious diversion targets of recyclable and organic waste of $25.8 \%$ and $18.1 \%$, respectively, were proposed for 2040 (MMA 2020).

Among the 34 sampled LCA papers from the past five years, 14 LCAs focus exclusively on waste collection, of which four were carried out in developing countries (Pop et al. 2017; Gilardino et al. 2017; Yıldız-Geyhan et al. 2019; Ferronato et al. 2021) and only consider the use of diesel as fuel for the waste collection vehicles (WCV). As for alternative fuels, five studies (all from developed countries) must be highlighted: Zabeo et al. (2017) analyzed the use of compressed natural gas (CNG) as a replacement for diesel; Pérez et al. (2017) compared replacing CNG, currently used in Madrid, Spain (3.2 million inhabitants), by biomethane; Costa et al. (2019) established a comparison between diesel and biomethane in Sinistra Piave Basin (population circa 300,000), Italy. The last two papers considered electricity as an energy source for the trucks. Winslow et al. (2019) assessed the diesel alternatives in Florida, USA, for landfill gas in MSW transport: upgrade to biomethane, electricity production to grid and to electric trucks. The study by Chàfer et al. (2019) adds hybrid technology to the scrutiny, by comparing diesel and dieselelectric, gas and gas-electric vehicles with fully electric collection trucks in Barcelona, Spain. 
Regarding the collection methods, half of the 14 studies feature more than one collection method, being the most frequent door-to-door (DtD) or Bring, where the residents have to dispose their waste in containers. Two studies (Chàfer et al. 2019; Pérez et al. 2020) show the environmental impact of a hightech method, pneumatic collection, while only one (Ferronato et al. 2021) has a low-tech method that is a cross between DtD and Bring: Corner Stop. In this method, the residents have to bring their waste to the WCV, that rings a bell when it stops in street intersections at certain schedules. Additionally, most studies consider MSW in general, but there are exceptions. Two studies focused on the organic fraction of MSW only (Laso et al. 2019; Pavlas et al. 2020) and the study by Costa et al. (2019) is even more specific, aimed at food waste and, lastly, Chàfer et al. (2019) excludes glass from MSW collection.

Several studies (Coelho and Lange 2018; Lima et al. 2018; Banias et al. 2020) evaluate an extensive array of treatments or management approaches, but consider a single collection method, which is already consolidated, or do not explore beyond commingled or source-separated collection (SSC). Regarding the location, there are still more LCA studies performed in developed countries, rather than in emergent ones, although this disparity is attenuating (Zhang et al. 2021). Specifically, the majority of studies on the collection phase (10 out of 14), were carried out in developed countries. Therefore, this review revealed that $C \& T$ is an area with opportunities to deepen the knowledge and obtain more specific answers.

Accordingly, this work is a novelty, as it intends to fill a gap by focusing on MSW collection in mid-sized metropolitan regions of developing countries, using an alternative fuel and different waste collection methods. The use of biomethane WCV, is a relevant matter, especially in these countries, since their waste has higher percentages of organic waste (Nizami et al. 2017), hence a higher potential for this fuel. The fact that gas engines emit less noise than they diesel counterparts (Milojevic et al. 2016) is not negligible in vehicles that operate in residential areas at night. Therefore, the general goal of this study is to find C\&T strategies with lower environmental impacts, by comparing diesel and biomethane scenarios, doorto-door vs Bring collection methods and different levels of SSC.

The adoption of policies and decision-making should be backed up by specific tools, like LCA, suggested in this study. So, this paper is aimed at the decision-makers of the municipalities of GVMR and any other similar regions, as well as the scientific community. To use this methodology in other regions, the steps are essentially the same, although the scenarios and strategies to propose may differ, according to local laws and regulations. It is noteworthy that the waste collection method is not independent from the treatment method, i.e., whether the waste in separated or commingled determines the downstream flow (Pires et al. 2019).

\section{Materials And Methods}

\subsection{Life Cycle Assessment}

To measure the impacts of different strategies to meet the diversion targets, LCA was used. This methodology specifically measures impacts on the environment (air, water and soil) and on human 
health, which is performed from the perspective of complete life cycles of products, processes or activities (Hauschild and Huijbregts 2015). This methodology has seen its ISO standards evolving since 1993 and is currently standardized by ISO 14040 and 14044 (ISO 2006a, 2006b), the norms used on this

study. LCA has four basic phases: (1) Goal and Scope, (2) Life Cycle Inventory, (3) Life Cycle Impact assessment, (4) Interpretation. Because of the uncertainty of the results and data availability, the earlier phases may need to be adjusted as needed.

In this paper, EASETECH, a Danish LCA software (Clavreul et al. 2014) was used, like in Lima et al. (2019, 2018). The choice for this tool is due to the fact that, unlike other LCA tools, it is a specific for waste management (Clavreul et al. 2014). This means thoroughly detailing the elements that comprise the mass and substance flows in each step of a waste management chain, instead of considering a single material flux (Laurent et al. 2014). Additionally, it contains libraries with models for all waste management phases: C\&T, waste treatments and recovery, and final disposal (Brogaard and Christensen 2016).

\subsection{Goal and Scope}

The goal of this paper is to compare scenarios with different combinations of collection types (DtD and Bring), different fuels (Diesel and Biomethane) in order to find out how to expand SSC while minimizing the rise of emissions that this action should hypothetically produce. As for the scope, the chosen functional unit was the collection and transport of one ton (1 t ) of MSW to facilities for materials recovery or final disposal (Gilardino et al. 2017). This study limits the LCA to the C\&T service only, leaving waste treatments and disposal outside this evaluation. Specifically, the analysis starts when the WCV leave their parking location to the collection routes and ends after the waste is transported directly to a waste disposal facility, or a sorting facility. In addition to the household waste, the incoming MSW flow includes pruning waste and waste from street cleaning services, complying with the PNRS (Brasil 2010).

\subsubsection{Studied area}

Espírito Santo (Fig. 1) is a small State in Southeast Brazil (with $46,096 \mathrm{~km}^{2}$ ). Its rising population of almost 4.0 million in 2019 (IBGE 2020) is estimated to reach 4.7 million in 2040 (ES 2019). The last census shows that $86 \%$ of the State's population is urban (IBGE 2010). This situation matches other regions of Brazil and other developing countries: population expansion in cities and rising waste generation.

Fig. 1 - Great Vitória Metropolitan Region

In this paper, the methodology for mid-sized urban areas of developing countries is applied on GVMR, shown in Fig. 1. This area, with almost 2 million inhabitants (ES 2019), is comprised of seven municipalities (ordered by population size): Serra, Vila Velha, Cariacica, Vitória, Guarapari, Viana and Fundão. The choice for this region is justified by the concentration of the majority of the state's 
population in this location, hence most of the MSW to be managed and the incipient rate of sourceseparated collection. The other municipalities of this State have a different MSW generation profile and are sparsely populated (compared to the GVMR), so they were excluded from this study, and must be analyzed separately.

\subsection{Life Cycle Inventory}

\subsubsection{Current MSW management panorama in the studied area}

The waste produced by GVMR is mostly brought to transfer stations (TS), by WCV via DtD collection. The ratio of DtD vs Bring collection varies between the municipalities. TS are the first MSW management facilities, where waste is gathered, so larger transport trucks carry it to either waste pickers organizations (recyclable fraction) or landfills (non-recyclables) - Fig. 1. And the source-separated organic fraction is transported in a composting facility located beside Cariacica landfill, that treated 5,193.23 t in 2020 (data from Organobom). This saves costs to transport MSW to final disposal facilities (ES 2019), which are, together with collection, the main operating expense in MSW management (Colvero et al. 2020b). Two small municipalities (Fundão and Viana) are the exception, by sending their waste directly to the landfill of Cariacica, located more than $25 \mathrm{~km}$ away. This is the limit beyond it is considered to be more economically viable to move the MSW to a higher capacity truck (Chen and Lo 2016). The TS of Guarapari also receives waste from five other neighbor municipalities, although this MSW was not accounted for in this study, because they were not produced in GVMR.

Commingled waste (97.2\%), is disposed of in the licensed landfills of Vila Velha and Cariacica (Table 1). Remains $1.132 \%$, which still represents 7.8 thousand tons yearly, a considerable amount of uncollected waste that can be either absorbed by the land (home composted), directly burned (for example, pruning waste), or worse, discarded in gutters (causing serious troubles), waterways and beaches (Fig. 2). The obtention of these data is explained in Section 1 of the Supplementary Material (SM) and the intermediate results are in SM Table 1. About the mentioned landfills, they both count on technologies like landfill gas recovery, environmental monitoring, rainwater and leachate drainage, internal leachate treatment and cover their waste daily (SNIS 2019). 
Table 1 - MSW panorama in Great Vitória Metropolitan Region.

\begin{tabular}{|c|c|c|c|c|c|c|c|c|}
\hline \multirow[t]{2}{*}{ Municipality } & $\begin{array}{c}\text { Total } \\
\text { population }\end{array}$ & $\begin{array}{l}\text { Popul. } \\
\text { Density } \\
\text { in 2020 } \\
\text { (ES2019) }\end{array}$ & $\begin{array}{l}\text { Transfer } \\
\text { station }\end{array}$ & $\begin{array}{c}\text { MSW } \\
\text { final disposal }\end{array}$ & $\begin{array}{c}\text { Population } \\
\text { covered by } \\
\text { MSW } \\
\text { collection } \\
\text { service }\end{array}$ & $\begin{array}{l}\text { Collection } \\
\text { per capita }\end{array}$ & $\begin{array}{c}\text { Source- } \\
\text {-separated } \\
\text { collection of } \\
\text { recyclables } \\
\text { per capita }\end{array}$ & $\begin{array}{c}\text { Population } \\
\text { covered by } \\
\text { DtD } \\
\text { collection }\end{array}$ \\
\hline & inhabitants & inh $\cdot \mathrm{km}^{-2}$ & & disposal location & inhabitants & $\mathrm{kg} \cdot \mathrm{inh} \mathrm{h}^{-1} \cdot \mathrm{day^{-1 }}$ & $\mathrm{kg} \cdot \mathrm{inh}^{-1} \cdot$ year ${ }^{-1}$ & inhabitants \\
\hline Cariacica & 381,285 & 1,406 & Private & Landfill Cariacica & 378,705 & 0.68 & 1.69 & 258,627 \\
\hline Fundão & 20,757 & 78 & No & Sent to Aracruz & 17,530 & 0.56 & 0.00 & 17,530 \\
\hline Guarapari & 123,166 & 220 & Private & Sent to Vila Velha & 115,777 & 1.38 & 4.25 & 111,320 \\
\hline Serra & 517,510 & 988 & Public & Sent to Cariacica & 517,510 & 0.71 & 0.88 & 513,948 \\
\hline Viana & 78,239 & 260 & No & Sent to Cariacica & 71,777 & 0.55 & 2.51 & 71,777 \\
\hline Vila Velha & 493,838 & 2,447 & Private & $\begin{array}{l}\text { Landfill Vila } \\
\text { Velha }\end{array}$ & 491,443 & 1.20 & 1.60 & 491,443 \\
\hline Vitória & 362,097 & 3,818 & Private & Sent to Cariacica & 362,097 & 1.20 & 8.59 & 362,097 \\
\hline TOTAL & $1,976,892$ & & & & $1,954,839$ & & & $1,826,742$ \\
\hline
\end{tabular}

Source: ES (2019), SNIS (2020) for all municipalities, except Fundão and Guarapari (SNIS 2019b).

Fig. 2 - Sankey diagram of the MSW flow of the current management panorama in Great Vitória Metropolitan Region

Source: (SNIS 2020, 2019b).

Regarding the SSC rate, only $1.57 \%$ ( $0.75 \%$ organic +0.82 recyclable) of the generated MSW in GVMR is collected separately at the source, which is incipient (Table 1). It can be collected via DtD collection, drop-off points on the streets (Bring collection) and directly from companies (Commercial). Furthermore, the same collection route can include households, as well as drop-off points and/or companies (blending different collection types, hence Blend collection). Additionally, Fundão does not practice SSC, despite of being a small peripheric rural municipality that absorbs considerable amounts of biowaste. Another consideration is that glass is currently landfilled. As there are still no recycling industries in ES, sending glass to a recycling industry in another state turns out to be unfeasible economically.

\subsubsection{Waste characterization for the studied area}

The basic MSW composition in the GVMR was initially estimated from the amounts of recyclable waste for each type of collection (Bring, DtD, Commercial and Blend). These data were kindly provided by LAGESA-UFES and were obtained from waste pickers organizations for all municipalities of the GVMR, except Fundão ( $0 \%$ SSC). Therefore, the basic recyclable waste characterization was: $45 \%$ paper/ multilayered packaging, $2.2 \%$ metals, $18 \%$ glass, $14 \%$ plastic, $5.8 \%$ Styrofoam, $6.2 \%$ others, $8.5 \%$ refuse.

Then, the biowaste, that includes pruning and gardening waste from public green spaces (Brasil 2010), was added for the seven municipalities of GVMR - 49.02\% for the year 2017 (ES 2019). Therefore, the complete basic estimated characterization of the waste generated in the GVMR was: $49.02 \%$ of organic waste, $23.1 \%$ paper/multilayered packaging, $1.1 \%$ metals, $9.1 \%$ glass, $7.2 \%$ plastic, $3 \%$ Styrofoam, 3.2\% others, $4.3 \%$ refuse. These values were used to proportionally estimate the detailed characterization for GVMR within each category to be inputted in the LCA software, using the proportions of each subdivisions of waste for Goiás, by Lima et al. (2018), which is presented in Table 2. In order to keep the 
values consistent with the authors, it was assumed that the fraction of "others" (3.2\%) from the surveyed data was Other non-combustibles in the detailed characterization, while "refuse" (4.3\%) was the sum of Reject with Hazardous waste.

Table 2 - Estimated MSW characterization for Great Vitória Metropolitan Region.

\begin{tabular}{lrll} 
Paper & $23.06 \%$ & Plastic (continued) & \\
Office paper & $9.95 \%$ & Soft plastic (2D Plastic) & $4.01 \%$ \\
Dirty paper & $0.80 \%$ & Plastic products (Other plastic) & $0.75 \%$ \\
Magazines & $0.20 \%$ & Non-recyclable plastic (Styrofoam) & $2.97 \%$ \\
Newsprints & $0.80 \%$ & Organic & $49.02 \%$ \\
Other clean cardboard & $10.21 \%$ & Vegetable food waste & $43.14 \%$ \\
Juice cartons (Multilayered & $1.10 \%$ & Animal food waste & $5.88 \%$ \\
packaging) & & & \\
\hline Metal & $\mathbf{1 . 1 4 \%}$ & Reject & $\mathbf{7 . 4 1 \%}$ \\
\hline & $1.02 \%$ & Diapers, sanitary towels, tampons & $1.28 \%$ \\
Food cans (Ferrous metal) & & (Sanitary waste) & \\
Beverage cans (Aluminum) & $0.11 \%$ & Rubber & $0.23 \%$ \\
\hline Glass & $\mathbf{9 . 1 0 \%}$ & Shoes, leather & $0.19 \%$ \\
Clear glass & $7.58 \%$ & Other combustibles (Foam) & $0.09 \%$ \\
Brown glass (Colored glass) & $1.52 \%$ & Textiles & $2.11 \%$ \\
\hline Plastic & $\mathbf{1 0 . 1 7 \%}$ & Wood & $0.33 \%$ \\
Hard plastic & $2.06 \%$ & Other non-combustibles & $\mathbf{3 . 1 8 \%}$ \\
Plastic bottles (PET) & $0.37 \%$ & Hazardous waste & $0.11 \%$ \\
& Continues in next column... & TOTAL & $\mathbf{1 0 0 . 0 0 \%}$ \\
\hline
\end{tabular}

Note: the numbers in bold-italic are the initial values from GVMR, obtained from the waste pickers' organizations and ES (2019). The remaining were estimated from the proportions of Lima et al. (2018).

\subsubsection{Proposed scenarios}

In order to find the best C\&T strategies, establishing scenarios to compare with the current panorama (Baseline scenario) is necessary. To do so, the eight hypothetical scenarios (Table 3) based on the provisional PLANARES (MMA 2012) waste diversion targets from 2031 (SM Table 2) will be presented in this item. 


\begin{tabular}{|c|c|c|c|c|}
\hline \multirow{5}{*}{$\begin{array}{l}\text { 0. Baseline } \\
\text { Scenario }\end{array}$} & & & Diesel & Biomethane \\
\hline & \multirow{2}{*}{$\begin{array}{c}\text { Low } \\
\text { Diversions (LD) }\end{array}$} & \multirow{2}{*}{$\begin{array}{l}\text { Door-to-Door } \\
\text { Bring }\end{array}$} & 1.Diesel LD DtD & 2. Biomethane LD DtD \\
\hline & & & 3.Diesel LD Bring & 4. Biomethane LD \\
\hline & \multirow{2}{*}{$\begin{array}{c}\text { High } \\
\text { Diversions (HD) }\end{array}$} & \multirow{2}{*}{$\begin{array}{l}\text { Door-to-Door } \\
\text { Bring }\end{array}$} & 5.Diesel HD DtD & 6. Biomethane HD DtD \\
\hline & & & 7.Diesel HD Bring & 8. Biomethane HD Bring \\
\hline
\end{tabular}

The Baseline scenario (0) was built according to the flows shown on Fig. 2. As for the proposed scenarios, in addition to the targets, the sorting efficiency of the materials recovery facilities (MRFs) was taken into account. To attain the diversion targets, the actual amount of waste to be collected has to be higher than the target itself, as some source-separated waste cannot be recycled or composted and will be landfilled anyway. So, using data from Portuguese waste biowaste and recycling plants (APA 2019), it was possible to estimate efficiency values to calculate the real collection amount to guarantee the diversion targets.

So, for the $L D$ scenarios (1 to 4 ), the average value of the Portuguese sorting facilities efficiencies (76\%) was used, while for the $H D$ scenarios (5 to 8 ) a figure of $95 \%$ represents the high-tech MRFs. Likewise, for organic pretreatments, the values assumed were $64.7 \%$ and $82.4 \%$, respectively. With the waste characterization and the Baseline and proposed scenarios defined, the mass of each type of waste was calculated (SM Tables 3 to 5 . Odd scenarios use diesel, whereas even scenarios use biomethane. Scenarios 1, 2, 5, 6 use DtD collection, whereas 3, 4, 7, 8 use Bring collection (Table 3). The overall preliminary waste distribution for both scenarios is shown in Fig. 3.

Fig. 3 - Sankey diagrams of the proposed low $(L D)$ and high diversions $(H D)$ scenarios

\subsubsection{Collection types, transport and fuel consumption}

DtD collection, also called curbside, full-service, alley pickup and house containers (Rodrigues et al. 2016), consists in a vehicle, with a scheduled route timetable, picking up the waste bags that are left by the citizens next to their door, at the sidewalk (Martinho et al. 2017). Alternatively, waste can be also deposited in 15 to 30-liter containers at each household doorstep or 360 liters in case of restaurants or shops (Tsalis et al. 2018). According to Martinho et al. (2017), the advantage of this method is the improved quality of recyclable materials, or a lower fraction of contaminants. Another plus is the comfort for the citizens, as they do not need to walk to a container to dispose of the waste, which reportedly results in twice the SSC than in drop-off collection ( $27 \mathrm{vs} 13 \mathrm{~kg} \cdot$ inhabitant $^{-1} \cdot \mathrm{year}^{-1}$ ), according to Dahlén and Lagerkvist (2010), but they have to commit to the specific waste truck schedule. A study conducted in Bari, Southern Italy, has revealed that the satisfaction level of the population with this mode is generally good (Laurieri et al. 2020) and from a sample of 150 citizens from Xanthi, Greece, $72.7 \%$ were keen on replacing the current collection system with DtD collection. (Tsalis et al. 2018). However, Calabrò 
and Satira (2020) affirm that this method requires educational programs in order to foster extensive public engagement.

In turn, drop-off or Bring systems (Rodrigues et al. 2016) require the citizens to collaborate and bring their waste to the street containers. According to Martinho et al. (2017) the collection truck takes less time to collect the waste (less stops and lower stopping time) and less workers are required, because they do not need to fetch the waste bags in every door. As for the downsides of this method: lower potential for source-separation (Laurieri et al. 2020); higher contamination of organic waste than in the DtD method, which invalidates the use of digestate from anaerobic digestion as a natural fertilizer (Gredmaier et al. 2013). The authors suggest this method when organic waste contamination is not a problem and householders are disciplined, as the fuel consumption is lower than DtD.

Lastly, commingled, mixed or undifferentiated waste collection, uses rear-loading 10t-trucks to carry waste to the TS (Lima et al. 2019). This waste can be either be collected from households or waste bins scattered in the streets. This method is the least fuel-consuming, but contamination can be a problem for waste treatments. Teixeira et al. (2014) reports that commingled collection when compared to DtD collection. decreases the collection distance per ton of waste to $13 \%$, approximately one fourth of the fuel consumption, one fifth of the cost and 4 -fold more crew productivity $\left(\mathrm{t} \cdot \mathrm{h}^{-1} \cdot\right.$ worker $\left.^{-1}\right)$.

The main element that distinguishes the environmental impact of the different types of collection is the amount of fuel burned by the collection trucks (assuming that trucks are used to collect the waste). Various factors influence consumption figures, such as vehicle automation level, the skill of the crew (Jaunich et al. 2016) and waste density . Since the fuel consumption of the WCV of GVMR was not available, the consumption figures used on this study, in liters per ton of collected waste $\left(\mathrm{L} \cdot \mathrm{t}^{-1}\right)$, were obtained from the average of values found in the literature, which are presented in Table 4. Note should be made that the extreme values for commingled collection, using diesel, are from two Brazilian studies. For DtD collection, the variance is higher, but the value from Paes et al. (2020) is, again a low extreme, while Lima et al. (2019) indicated an intermediate value, but higher than average. Although the values used are from different countries, even in different cities from the same country, the result may vary substantially, so when local data is unavailable, a sensitivity analysis is strongly advised.

Additionally, the mean consumption in $\mathrm{km}$ per liter of fuel $\left(\mathrm{km} \cdot \mathrm{L}^{-1}\right)$ of diesel was estimated from the literature (Table 4), in order to calculate the emissions for both fuels, described in item 2.3.5. This value ranged between 0.85-1.3 km. $\mathrm{L}^{-1}$ (Clark et al. 1998; Agar et al. 2007; Hesterberg et al. 2008; Thiruvengadam et al. 2010; Fontaras et al. 2012) and 1-1.4 km· $\mathrm{L}^{-1}$ (Sandhu et al., 2014).

Biogas can be produced by anaerobic digestion of biowaste in biodigesters, landfill gas recovery systems, as well as wastewater treatment plants (IEA 2020). To be useable as a fuel in vehicles, biogas must be "upgraded", since this gas is mainly constituted by methane (50-60\%), hydrogen sulfide $\left(\mathrm{H}_{2} \mathrm{~S}\right), \mathrm{CO}_{2}$ and trace elements in variable proportions. This treatment nearly purifies biogas into biomethane, by removing $\mathrm{H}_{2} \mathrm{~S}$, which is corrosive, water (liquid and vapor) and $\mathrm{CO}_{2}$, using technologies like water 
scrubbing, adsorption and membrane separation (Awe et al. 2017; IEA 2020), making it equivalent to natural gas. Then, biomethane can be compressed or liquefied. Since its lower heating value is inferior than diesel's, a 10\% increase in consumption per km, was assumed, as Cong et al. (2017) and Jensen et al. (2017).

Table 4 - Consumption values used in the simulation

\begin{tabular}{|c|c|c|c|}
\hline & $\begin{array}{c}\text { Commingled } \\
\text { collection } \\
\end{array}$ & $\begin{array}{l}\text { Door-to-door separated } \\
\text { collection }\end{array}$ & $\begin{array}{l}\text { Drop-off separated } \\
\text { collection }\end{array}$ \\
\hline Diesel Collection $\left(1.1375 \mathrm{~km} \cdot \mathrm{L}^{-1}\right)$ & $\left({\left.\mathrm{L} \cdot \mathrm{t}^{-1}\right)}^{2}\right.$ & $\left(\mathrm{L} \cdot \mathrm{t}^{-1}\right)$ & $\left(\mathrm{L} \cdot \mathrm{t}^{-1}\right)$ \\
\hline Teixeira et al. (2014) - Portugal & 3.96 & 15.37 & - \\
\hline Lima et al. (2019) - Brazil & 4.3 & 11.3 & - \\
\hline Larsen et al. (2009) - Denmark & 3 & - & - \\
\hline Nguyen and Wilson (2010) - Canada & 3.2 & 12.9 & - \\
\hline $\begin{array}{l}\text { Møller and Christensen (2007) - } \\
\text { Denmark }\end{array}$ & - & 7.2 & - \\
\hline Paes et al. (2020) - Brazil & 2.43 & 7.06 & - \\
\hline Gredmaier et al. (2013) - Germany/UK & - & 10.9 & $4.1 ; 4.3$ \\
\hline Min.; Average; Max. & $\begin{array}{c}2.43 ; \\
3.38 ; 4.3\end{array}$ & $7.06 ; 10.8 ; 15.37$ & $4.1 ; 4.25 ; 4.4$ \\
\hline $\begin{array}{l}\text { Std. dev. } \\
\end{array}$ & $\sigma=0.67$ & $\sigma=2.96$ & $\sigma=0.10$ \\
\hline \multicolumn{4}{|c|}{ Biomethane Collection $\left(1.1375+10 \%=1.25125 \mathrm{~km} \cdot \mathrm{L}^{-1}\right)$} \\
\hline $\begin{array}{l}\text { Diesel Transport }\left(\mathrm{L} \cdot \mathrm{t}^{-1}\right) \\
\text { Biomethane Transport }\left(\mathrm{L} \cdot \mathrm{t}^{-1}\right)\end{array}$ & \multicolumn{3}{|c|}{$\begin{array}{l}0.06 \cdot[\text { distance in } \mathrm{km} \text { ] (Lima et al. 2018) } \\
(0.06+10 \%) \cdot[\text { distance in } \mathrm{km} \text { ] }\end{array}$} \\
\hline
\end{tabular}

For the Baseline scenario, that also contemplates two more methods, Commercial collection was attributed the same value as the DtD collection value $\left(10.8 \mathrm{~L} \cdot \mathrm{t}^{-1}\right)$. This is because WCV pick the waste from the companies like in households. As for Blend collection, there is no information on how much DtD vs Bring collection. But, since the established method in GVMR is DtD, a weight proportion of 70/30 (DtD/Bring) was considered to calculate the unit consumption of blend collection $-8.83 \mathrm{~L} \cdot \mathrm{t}^{-1}$. In any case, the uncertainty of this number only affects a fraction of the almost insignificant SSC rate $(0.74 \%)$.

Regarding the transport of MSW accumulated in TS (in larger trucks, as described by the end of item 2.3.1), the calculations differ from collection, as the distance now is taken into account, as in Colvero et al. (2020). Since this study focuses on the entire GVMR, the distances used to compute the consumptions/emissions were the average value of all transport distances to landfills ( $29.46 \mathrm{~km}-\mathrm{SM}$ Table 6) and to waste pickers organizations (7.49 km - SM Table 7). For the transport with biomethane, a $10 \%$ increase in consumption was assumed, just as in the collection phase (Cong et al., 2017; Jensen et al., 2017).

\subsubsection{Emission factors}

Regarding the emission factors for each pollutant, as the Ecoinvent database has a complete dataset for diesel WCV, but not for gas WCV. For this reason, these data were not used. Instead, the emission factors 
of carbon dioxide and monoxide $\left(\mathrm{CO}_{2}\right.$ and $\left.\mathrm{CO}\right)$, nitrogen oxides $\left(\mathrm{NO}_{\mathrm{X}}\right)$, hydrocarbons $(\mathrm{HC})$ and particulate matter (PM) were obtained from Farzaneh et al. (2009), Fontaras et al. (2012) and Sandhu et al. (2014) for diesel, and from Alberici et al. (2003), Hesterberg et al. (2008), López et al. (2009), ASM et al. (2002), Fontaras et al. (2012), Sandhu et al. (2020) for natural gas/biomethane (SM Table 8), so the comparison would encompass the same categories of pollutants. Therefore, the average of the values collected from the literature per km travelled both for diesel and biomethane is presented in Table 5, in italic.

Regarding the unit emissions, it is worth mentioning that, although biomethane is believed to be a "clean fuel" and the $\mathrm{PM} / \mathrm{NO}_{\mathrm{X}}$ emissions are 9-10 times lower, heavy-duty diesel vehicles can still produce less $\mathrm{CO}_{2}$, due to a better fuel consumption and substantially less $\mathrm{CO}$ and $\mathrm{HC}$. About the type of $\mathrm{HC}$, diesel engines emit non-methane volatile organic compounds, whereas of natural gas/biomethane engines, $>95 \%$ of exhaust $\mathrm{HC}$ is methane, according to Yoon et al. (2013).

Table 5 - Mean value of emission factors found in the literature.

\begin{tabular}{|c|c|c|c|c|c|}
\hline & $\mathrm{CO}_{2}$ & CO & $\mathbf{N O}_{\mathbf{x}}$ & HC & PM \\
\hline & $\begin{array}{c}\boldsymbol{k g} \cdot \boldsymbol{k m} \mathbf{m}^{-1} \\
\mathrm{~kg} \cdot \mathrm{kg}_{\text {waste }}{ }^{-1}\end{array}$ & $\begin{array}{c}\mathbf{k g} \cdot \boldsymbol{k m}^{-1} \\
\mathrm{~kg} \cdot \mathrm{kg}_{\text {waste }^{-1}}\end{array}$ & $\begin{array}{c}\boldsymbol{k g} \cdot \boldsymbol{k m}^{-1} \\
\mathrm{~kg} \cdot \mathrm{kg}_{\text {waste }}{ }^{-1}\end{array}$ & $\begin{array}{c}\mathbf{k g} \cdot \mathbf{k m}^{-1} \\
\mathrm{~kg} \cdot \mathrm{kg}_{\text {waste }^{-1}}\end{array}$ & $\begin{array}{c}\boldsymbol{k g} \cdot \boldsymbol{k m} \boldsymbol{m}^{-1} \\
\mathrm{~kg} \cdot \mathrm{kg}_{\text {waste }}{ }^{-1}\end{array}$ \\
\hline Diesel-Average & 2.57 & $1.03 \cdot 10^{-2}$ & $2.15 \cdot 10^{-2}$ & $1.32 \cdot 10^{-3}$ & $9.60 \cdot 10^{-5}$ \\
\hline Std. $\operatorname{dev} .(\sigma)$ & 0.17 & $4.80 \cdot 10^{-3}$ & $7.72 \cdot 10^{-3}$ & $1.30 \cdot 10^{-3}$ & $6.11 \cdot 10^{-5}$ \\
\hline \multicolumn{6}{|c|}{ Farzaneh et al. (2009); Fontaras et al. 2012); Sandhu et al. (2014) } \\
\hline Commingled collection & $9.86 \cdot 10^{-3}$ & $3.97 \cdot 10^{-5}$ & $8.24 \cdot 10^{-5}$ & $5.07 \cdot 10^{-6}$ & $3.69 \cdot 10^{-7}$ \\
\hline Door-to-door (DtD) collection & $3.15 \cdot 10^{-2}$ & $1.27 \cdot 10^{-4}$ & $2.63 \cdot 10^{-4}$ & $1.62 \cdot 10^{-5}$ & $1.18 \cdot 10^{-6}$ \\
\hline Bring collection & $1.24 \cdot 10^{-2}$ & $4.99 \cdot 10^{-5}$ & $1.04 \cdot 10^{-4}$ & $6.38 \cdot 10^{-6}$ & $4.64 \cdot 10^{-7}$ \\
\hline Blend ( $70 \% \mathrm{DtD} / 30 \%$ Bring) & $2.58 \cdot 10^{-2}$ & $1.04 \cdot 10^{-4}$ & $2.15 \cdot 10^{-4}$ & $1.33 \cdot 10^{-5}$ & $9.64 \cdot 10^{-7}$ \\
\hline Biomethane - Average & 2.69 & $1.36 \cdot 10^{-2}$ & $2.86 \cdot 10^{-3}$ & $2.27 \cdot 10^{-3}$ & $1.49 \cdot 10^{-5}$ \\
\hline Std. dev. $(\sigma)$ & 0.80 & $5.29 \cdot 10^{-3}$ & $1.93 \cdot 10^{-3}$ & $9.48 \cdot 10^{-3}$ & $7.72 \cdot 10^{-6}$ \\
\hline
\end{tabular}

Alberici et al. (2003); Fontaras et al. (2012); Hesterberg et al. (2008); López et al. (2009); Sandhu et al. (2020); EEA (2009)

\begin{tabular}{lccccc}
\hline Commingled biomethane collection & $1.14 \cdot 10^{-2}$ & $5.76 \cdot 10^{-5}$ & $1.21 \cdot 10^{-5}$ & $9.58 \cdot 10^{-6}$ & $6.28 \cdot 10^{-8}$ \\
DtD biomethane collection & $3.63 \cdot 10^{-2}$ & $1.84 \cdot 10^{-4}$ & $3.86 \cdot 10^{-5}$ & $3.06 \cdot 10^{-5}$ & $2.01 \cdot 10^{-7}$ \\
Bring biomethane collection & $1.43 \cdot 10^{-2}$ & $7.24 \cdot 10^{-5}$ & $1.59 \cdot 10^{-5}$ & $1.21 \cdot 10^{-5}$ & $7.90 \cdot 10^{-8}$ \\
\hline Comparison biomethane/diesel & $+11 \%$ & $+32 \%$ & $-87 \%$ & $+72 \%$ & $-83 \%$ \\
$\mathrm{~kg}^{-\mathrm{km}^{-1}}\left(\mathrm{~kg} \cdot \mathrm{kg}_{\text {commingled waste }}{ }^{-1}\right)$ & $(+15 \%)$ & $(+45 \%)$ & $(-85 \%)$ & $(+89 \%)$ & $(-83 \%)$ \\
\hline
\end{tabular}

$\left(\mathrm{CO}_{2}\right)$ Carbon Dioxide, (CO) Carbon Monoxide, $\left(\mathrm{NO}_{\mathrm{X}}\right)$ Nitrogen Oxides, $(\mathrm{HC})$ Hydrocarbons, (PM)

Particulate Matter

For Collection, in order to convert the obtained values in $\mathrm{km}$ to wet weight basis, to be inputted in EASETECH, Equation 1 was applied:

$$
E_{w w}=F_{e f f} \cdot C_{w w} \cdot C_{d s t} \quad \mathrm{c}
$$

in which $E_{w w}$ is the emission of a pollutant per weight unit of collected MSW $\left(\mathrm{kg}_{\text {emitted }} \mathrm{kg}_{\text {waste }}{ }^{-1}\right), \mathrm{F}_{\text {eff }}$ is the fuel efficiency, in distance travelled per unit of fuel $\left(\mathrm{km} \cdot \mathrm{L}^{-1}\right), C_{w}$ is the consumption per weight unit 
of collected MSW $\left({\mathrm{L} \cdot \mathrm{kg}_{\text {waste }}}^{-1}\right)$ and $\mathrm{C}_{\mathrm{dst}}$ is the distance travelled per unit of fuel $\left(\mathrm{km} \cdot \mathrm{L}^{-1}\right)$.

Since the consumption value per unit weight of collected waste $\left(C_{w}\right)$ is different for each collection type, so are the emissions $\left(E_{w w}\right)$. So, these had to be calculated for all collection types, which are also presented in Table 5. With these values, the amount of emitted pollutants can be estimated, just by multiplying them by the amounts of collected waste.

For Transport, the process is similar, with the detail of $C_{w}$ being a function of distance, in $\mathrm{km}$ (Table 4). The distance values and their calculation are patent in SM Tables 6 and 7. These steps, together with the MSW weight values from Items 2.3.2 and 2.3.3 (which are indicated in SM Tables 3 to 5) have allowed to obtain the inventory of the emissions for each scenario, presented in SM Table 9.

\subsection{Impact assessment}

The life cycle impact assessment method used was International Reference Life Cycle Data System (ILCD) (EC-JRC 2010), with six impact categories: Climate change (GWP100), Particulate Matter smaller than $2.5 \mu \mathrm{m}(P M 2.5)$, Photochemical Ozone Formation (POF), Terrestrial Acidification (TA), Eutrophication Terrestrial $(E T)$ and Eutrophication Marine ( $E M)$. These impact categories measure the impacts associated with the emission values obtained from the literature. The unit impacts per $\mathrm{kg}$ of emissions for this method are indicated in SM Tables 10 and 11 for diesel and biomethane, respectively. The ILCD-recommended normalization factors from SM Table 12 were used to convert the values in mili Person Equivalents (mPE), therefore allowing for the comparison between impact categories.

\subsubsection{Sensitivity analysis}

There are various parameters with uncertainties due to the shortage of available primary data, which is a common problem in developing countries that hinders the possibility of carrying out reliable studies for these regions (Laurent et al. 2014). Therefore, according to (ISO 2006a, 2006b), a sensitivity analysis was performed (Pires et al. 2017; Pérez et al. 2017, 2020; Lima et al. 2018, 2019). These uncertainties refer, mostly, to estimated waste characterization and generation, unit emissions and fuel consumption and travelled distances. In order to account for the variation of secondary data, the LCA was repeated four times, using sets of the minimum and maximum values found on literature for each emitted substance (SM Table 8) and fuel consumption for each collection type (Table 4). As for transport, a $\pm 20 \%$ variation was set for the consumption figures in the second sensitivity analysis. For C\&T with biomethane, the 10\% decrease in fuel economy was left unchanged.

\section{Results And Discussion}

\subsection{Interpretation}


Figure 4 shows the normalized LCA outputs, also available numerically in SM Tables 13 and 14. Comparing the Baseline scenario with the proposed diesel scenarios, which expand SSC (from $1.12 \%$ to $60.0-70.6 \%$ of the total weight generated - Fig. 3 ) and now account of $1.13 \%$ of uncollected waste, there are mainly two very different results. In the Bring scenarios a $3 \%$ decrease in total environmental impacts can be observed. This is because of the important savings in the Transport part, that compensated the increase of $15-18 \%$ in the Collection fraction. Contrarywise, in the DtD scenarios, the impacts increased by $76-90 \%$, yet the absolute value is small, considering the values of studies that included the remaining steps of managing $1 \mathrm{t}$ of MSW (Lima et al. 2018; Colvero et al. 2020a).

Figure 4 - Normalized results with the respective errors for collection/transport using diesel and biomethane

a, c: values and errors calculated using extreme emission values; b, d: values and errors calculated using extreme fuel consumption values. (GWP100) Climate change, (PM2.5) Particulate Matter < $2.5 \mu \mathrm{m}$, (POF) Photochemical Ozone Formation, (TA) Terrestrial Acidification, (ET) Eutrophication Terrestrial, (EM) Eutrophication Marine. (LD) Low Diversions. (HD) High Diversions.

Still on the Transport component, surprisingly, in this particular case, not only the proposed diesel scenarios performed better than the baseline scenario ( 0 ) by $39-47 \%$, but scenarios 5 and 7 , with high diversions have performed better than the other two ( 1 and 3$)$ with lower diversions. This detail can be explained by the smaller transport distance (SM Tables 6 and 7) from the TS to the sorting facilities (7.5 $\mathrm{km}$ ) versus the average distance to the landfills $(29.5 \mathrm{~km})$ in this metropolitan area, which directly influences fuel consumption (Table 4). So, minimizing the distance between waste management facilities is crucial on fuel consumption, that influences environmental, economic and operational performance (Teixeira et al. 2014). But choosing these locations requires observing the Brazilian laws and regulations that permit or restrict construction areas for these facilities, based on multiple criteria (Colvero et al. 2018). Furthermore, the Transport is lower than Collection in all scenarios, as the Transport consumption is much smaller than Collection, in GVMR. This fact shows the importance of using TS to transport waste in larger vehicles, which is not currently done by Fundão and Viana.

As for the alternative biomethane scenarios, they performed much better in all impact categories, especially in the Climate change (GWP100), which is $96 \%$ less than the Baseline scenario (SM Tables 13 and 14). For the remaining biomethane scenarios, the impacts decreased in $75-77 \%$ in the $T A, E T$ and $E M$ categories, $72-74 \%$ for $P O F$, and $7072 \%$ for $P M 2.5$, compared to the Baseline scenario. Like in the diesel scenarios, for the Bring scenarios, the $H D$ scenario also had a total impact slightly inferior to the $L D$ scenario in all impact categories. Again, the decrease of transport impacts, explained above, was higher than the increase in the collection impacts, due to the increase in SSC, in which the facilities are closer than landfills.

As for which impacts are higher in relative terms (compared to the total impact of each scenario) for both fuels, the major difference is in GWP100 (15\% - diesel vs 3\% - biomethane), which is a concern for diesel. Oppositely, POF is proportionally higher for biomethane (27\% vs $34 \%)$. For the remaining 
categories, the percentages are similar (differences of 1-2\%). In respect to the emissions that motivate those impacts, analyzing Table 5, allows to infer that for the same collection type, diesel WCV emit less $\mathrm{CO}_{2}(-13 \%)$ and $\mathrm{CO}(-31 \%)$, which is partly motivated by a $10 \%$ better fuel economy, but also the incomplete combustion of gas (Paolini et al. 2018).

Additionally, biomethane vehicles produce about $85 \%$ less $\mathrm{NO}_{x}$ and $\mathrm{PM}$. As for $\mathrm{HC}$, it can be a concern for CNG WCV, due to the fugitive methane leaks through the crankcase, tank venting and boil-off emissions, that can be mitigated (Clark et al. 2017). According to Cong et al. (2017), between 57-62\% of the methane emissions by biomethane vehicles are due to engine losses and fuel station losses. Cooper et al. (2019) confirms that the supply chain and fuel station methane emissions (which were not accounted in this study) are less impactful than tailpipe emissions. Nevertheless, methane has a GWP (over 100 years) 28 times higher than $\mathrm{CO}_{2}$, according to IPCC (2014), therefore emissions must be kept under 7.8-9 $\mathrm{g} \cdot \mathrm{km}^{-1}$ to guarantee a lower GWP100 than diesel (Cooper et al. 2019). Nevertheless, GWP100 is 15 times higher in diesel scenarios. This is because the $\mathrm{CO}_{2}$ emitted by diesel WCV is from a fossil source, whereas the $\mathrm{CO}_{2}$ from biomethane is considered non-fossil, so the impact is null (SM Tables 9 and 10), even though the amount of $\mathrm{CO}_{2}$ each produce is roughly the same. This is noteworthy, as the $\mathrm{CO}_{2}$ emissions are in the order of magnitude of $\mathrm{kg}$, whereas the emissions of hydrocarbons are 10 to 100 times lower.

Two indicators especially concern to air quality: for $P M 2.5$, the main contributors are $\mathrm{PM}, \mathrm{CO}$ and $\mathrm{NO}_{\mathrm{X}}$, while POF is affected by HC instead of PM (SM Tables 9 and 10). Firstly, biomethane performs much better than diesel in respect to PM, which affects PM2.5 the most. Secondly, although diesel engines produce $21 \%$ less CO than biomethane, which is in line with the study by Cooper et al. (2019) on natural gas trucks, this pollutant contributes little to the results: its impact is 10 times lower than $\mathrm{NO}_{\mathrm{X}}$, where biomethane also greatly surpasses diesel (-87\%). Regarding $P O F$, even though hydrocarbons are much higher on biomethane WCV, again, the type of $\mathrm{HC}$ makes the difference. In this case, on the opposite side: methane has 100 times less impact on $\mathrm{O}_{3}$ formation (which causes problems to the human health, at urban level) than the non-methane volatile organic compounds that diesels produce, according to the ECJRC (2010) unit impacts (SM Tables 9 and 10).

Expanding SSC in order to divert waste from landfills, via recycling and proper biowaste treatment, is not only a way to properly manage MSW to decrease environmental damage, but also a target to be attained. However to achieve these diversions, collecting and transporting MSW also has an environmental cost, even if it is undoubtably less than not collecting or landfilling (Coelho and Lange 2018; Lima et al. 2018, 2019). That said, when using diesel, the best theoretical scenario (HD DtD), i.e. that potentializes diversions the most, was also the worst, indicator-wise. However, the alternative of using biomethane can annulate this disadvantage for the environment, since its use can reduce to approximately $1 / 4$ the impact in the worst case (when the mean diesel result is compared with the maximum biomethane result in the $H D D t D$ scenario). Even though the impact of extraction, transport and distribution of these fuels was not taken into account, the results undoubtably point to the recommendation of using biomethane produced 
from biowaste and other organic matter by anaerobic digestion and, of course, to keep up with the once exigent PLANARES diversion targets.

In respect to the use of DtD vs Bring collection, the high level of diversions requires the collaboration of the citizens to separate their waste at the source. In the study by Di Maria and Micale (2013), the highest SSC rate scenario, with $52 \%$, requires DtD collection. Nevertheless, for the area they analyzed, an intermediate solution is suggested for economical and operational reasons: using both DtD collection for heavier waste, like glass, and Bring collection for light packaging and metals. On the contrary, for small towns with less than 5,000 inhabitants Gallardo et al. (2012) concluded that the preferable collection scheme is to use Bring collection for glass and DtD for the remaining fractions. And for populations of more than 50,000, the same authors obtained the best results with collecting commingled and biowaste DtD, and lightweight packaging and glass in drop-off containers. So, this choice should be made according to the municipality, since the population, density and waste characterization vary drastically. And, lastly, the municipalities that sent their waste to a landfill, situated more than $25 \mathrm{~km}$ away from the waste generating center, should establish TS, as the lack of them and the use of smaller sized trucks causes higher global warming factors (Yaman et al. 2019).

\subsection{Sensitivity analysis}

The result of the sensitivity analysis is shown in Fig. 4 and is detailed in SM Tables 15 to 18. The deviations can be significantly high (more than $100 \%$ in some situations) when the maximum and minimum values for consumption Table 4 and emissions (SM Table 11) are applied, in particular for the scenarios with DtD collection and certain impact categories. A direct proportionality relation is verified between the magnitude of the absolute values of deviation and the actual impact values. As the mentioned scenarios have the highest fuel consumption (and those vary between 7.06 and $15.37 \mathrm{~L} \cdot \mathrm{t}^{-1}$, more than double of the smallest value found on literature), not only their impacts are the greatest, but the same is also true for the deviation values.

Moreover, the impact category POF has the highest deviations (for both diesel and biomethane), as it is mostly affected by hydrocarbons, which have a high relative variation $(-84 \%,+139 \%$ for diesel and $-44 \%$, $+69 \%$ for biomethane - SM Table 8). ET is second on deviations, which in this case is affected by $\mathrm{NO}_{\mathrm{X}}$. Although NOx does not vary as much as hydrocarbons in diesel, it is one order of magnitude larger and has its unit impact multiplied by 4.26 , the highest unit impact. As for EM and TA, the deviations are similar (differential between both $<0.03 \mathrm{mPE}^{-1}-\mathrm{SM}$ Table 15), as both are affected by $\mathrm{NO}_{\mathrm{x}}$. In GWP100, the lower result in the Baseline scenario $\left(4.5 \mathrm{mPE}^{-1} \mathrm{t}^{-1}\right)$ in the emissions sensibility analysis (Fig. $4 \mathrm{~b}$ ) is

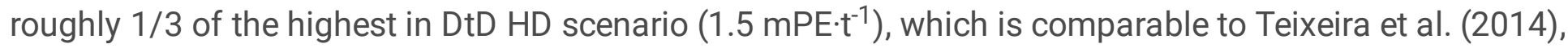
from Portugal.

So, the sensitivity analysis reveals that there are uncertainties from varying both the emissions and consumption values. This is a telltale that both these parameters require more attention in order to collect 
regional data and produce more reasonable studies. Specific factors like the type of WCV, geography and traffic of the city and building density (Gentil et al. 2010), vehicle's capacity use, MSW density, and driver's behavior can impact the fuel consumption significantly (Yaman et al. 2019). As for emissions, there are regional and technical particularities that affect these figures, such as fuel characteristics, used engine technology and maintenance. Due to the aging source of some data, it is possible that the evolution of technology may not be reflected accurately. Another uncertainty source in this study is waste generation and characterization, which is an estimate that crosses data from more than one source. Therefore, values found in the bibliography and databases may or may not reflect accurately the conditions of the studied region. Despite of those significant uncertainties and the exclusion of well-to-tank impacts, this did not change the recommendations and conclusions.

\section{Conclusions}

This study focused exclusively on MSW C\&T strategies for a midsized metropolitan area in a developing country, using a metropolitan area in Southwest Brazil as a subject. So, an LCA that compared a combination of two fuels (diesel vs biomethane), two levels of SSC (high vs low) and two types of collection (Bring vs DtD) to the current scenario was performed.

The results, with diesel, have shown that collecting all the waste and increasing the SSC rate to reach the waste diversion targets from landfills will increase the environmental impacts, but only if collection is performed DtD, because with Bring collection, the indicators show a marginal rise in the impacts. However, if biomethane vehicles are used, the impact is always inferior in relation to the diesel scenarios, by a large scale, even when taking the uncertainty of the results into account. Specifically, in this situation, since the transport distance to the sorting facilities is less than to the landfills, the scenarios with more SSC also diminished the transport impacts, which partially compensated for the increase in collection. This highlights the importance of selecting well the location of the waste management facilities to improve the performance of the system as a whole.

The recommendation is to use biomethane to decrease the impact in the C\&T phase. Additionally, the increased impacts of SSC should not get in the way of expanding it to divert waste from landfills, so the governments and public managers should not be uncertain to aim for $H D$ scenarios, environmentally speaking. As for the collection type DtD, it has the most potential to obtain uncontaminated sorted materials, but Bring can be used in conjunction with DtD for lower density materials, like light packaging or metals.

The development of this paper demonstrated the necessity of carrying out more studies to collect more regional data, especially in developing countries, on waste characterization, fuel consumption for C\&T and emissions for biomethane vehicles, in order to enhance LCA databases and improve the precision of further researches. Also, in this paper, only the fuel use was considered (tank-to-wheel). Even though biomethane can and should be produced by anaerobic digestion of organic waste, these impacts (well-totank) were not compared with the diesel production. Also, the vehicle and waste bin life cycle can also be 
accounted in future researches. Additionally, finding ways that agree with the local reality (culture, society, climate, economy) to encourage the collaboration of citizens to participate on waste management. This reveals a research gap, that is also an opportunity for future studies.

\section{Declarations}

Competing interests

The authors declare no competing interests

Acknowledgements

This study was partly financed by the Coordenação de Aperfeiçoamento de Pessoal de Nível Superior (College and Graduate Education Improvement Coordination), Brazil (CAPES), Finance Code 001. The authors also acknowledge the financial support given by Fundação de Amparo à Pesquisa e Inovação do Espírito Santo (Espírito Santo Research and Innovation Support Foundation - FAPES) project 107/2019.

\section{Abbreviations}




\begin{tabular}{|ll|}
\hline Acronym & Meaning \\
\hline C\&T & Collection and Transport of Municipal Solid Waste \\
\hline DtD & Door-to-door \\
\hline EM & Eutrophication marine \\
\hline ET & Eutrophication terrestrial \\
\hline GVMR & Great Vitória Metropolitan Region \\
\hline GWP100 & Global Warming Power - climate change in 100 years \\
H 2 S & Hydrogen sulfide \\
\hline LCA & Life Cycle Assessment \\
\hline LD & Low diversions scenario \\
\hline HD & High diversions scenario \\
\hline MSW & Municipal Solid Waste \\
\hline PLANARES & National Plan for Solid Waste Management (Plano Nacional de Resíduos Sólidos) \\
\hline PM & Particulate Matter \\
\hline POF & Photochemical Ozone Formation \\
\hline SM & Supplementary Material \\
\hline SSC & Source-Separated Collection \\
\hline TA & Terrestrial Acidification \\
\hline TS & Transfer Station \\
\hline WCV & Waste Collection Vehicle \\
\hline
\end{tabular}

\section{References}

Agar BJ, Baetz BW, Wilson BG (2007) Fuel Consumption, Emissions Estimation, and Emissions Cost Estimates Using Global Positioning Data. J Air Waste Manag Assoc 57:348-354.

https://doi.org/10.1080/10473289.2007.10465328

Alberici F, Callera G, Florio S (2003) Determinazione sperimentale delle emissioni allo scarico dimotori diesel di mezzi adibiti al transport publico ed al sevizio di raccolta RSU ed estensione relativa all uso di biodiesel (Experimental determination of the exhaust emissions of diesel engines of vehicles used for public transport and MSW collection service and extension relating to the use of biodiesel).

ENITecnologie, Sala Motori ed Emissioni SAMO 
APA - Agência Portuguesa do Ambiente (2019) Relatório anual de resíduos urbanos 2019 - fichas individuais por SGRU (Annual report on municipal waste 2019 - individual records by MSW management services)

ASM OMB, IVECO (2002) Progetto metano, studio di settore per un azienda di igiene urbana. ASM Brescia, Brescia

Awe OW, Zhao Y, Nzihou A et al (2017) A Review of Biogas Utilisation, Purification and Upgrading Technologies. Waste Biomass Valor 8:267-283. https://doi.org/10.1007/s12649-016-9826-4

Banias G, Batsioula M, Achillas C et al (2020) A Life Cycle Analysis Approach for the Evaluation of Municipal Solid Waste Management Practices: The Case Study of the Region of Central Macedonia, Greece. Sustainability 12:8221. https://doi.org/10.3390/su12198221

Brasil (2010) Política Nacional de Resíduos Sólidos (National Policy on Solid Waste)

Brogaard LK, Christensen TH (2016) Life cycle assessment of capital goods in waste management systems. Waste Manag 56:561-574. https://doi.org/10.1016/j.wasman.2016.07.037

Calabrò PS, Satira A (2020) Recent advancements toward resilient and sustainable municipal solid waste collection systems. Current Opinion in Green Sustainable Chemistry 26:100375. https://doi.org/10.1016/j.cogsc.2020.100375

Chàfer M, Sole-Mauri F, Solé A et al (2019) Life cycle assessment (LCA) of a pneumatic municipal waste collection system compared to traditional truck collection. Sensitivity study of the influence of the energy source. J Clean Prod 231:1122-1135. https://doi.org/10.1016/j.jclepro.2019.05.304

Chen Y-C, Lo S-L (2016) Evaluation of greenhouse gas emissions for several municipal solid waste management strategies. J Clean Prod 113:606-612. https://doi.org/10.1016/j.jclepro.2015.11.058

Clark NN, McKain DL, Johnson DR et al (2017) Pump-to-Wheels Methane Emissions from the Heavy-Duty Transportation Sector. Environ Sci Technol 51:968-976. https://doi.org/10.1021/acs.est.5b06059

Clark NN, Rapp BL, Gautam M et al (1998) A Long Term Field Emissions Study of Natural Gas Fueled Refuse Haulers in New York City. SAE Trans 107:964-975

Clavreul J, Baumeister H, Christensen TH, Damgaard A (2014) An environmental assessment system for environmental technologies. Environ Model Softw 60:18-30.

https://doi.org/10.1016/j.envsoft.2014.06.007

Coelho LMG, Lange LC (2018) Applying life cycle assessment to support environmentally sustainable waste management strategies in Brazil. Resour Conserv Recycl 128:438-450.

https://doi.org/10.1016/j.resconrec.2016.09.026 
Colvero DA, Gomes APD, Matos MAA et al (2020a) Avaliação do ciclo de vida de um sistema de gestão de RSU em uma região metropolitana. A\&R 17-28. https://doi.org/10.22181/aer.2020.0902

Colvero DA, Gomes APD, Tarelho LA da C, et al (2018) Use of a geographic information system to find areas for locating of municipal solid waste management facilities. Waste Manag 77:500-515. https://doi.org/10.1016/j.wasman.2018.04.036

Colvero DA, Ramalho JCM, Gomes APD et al (2020b) Economic analysis of a shared municipal solid waste management facility in a metropolitan region. Waste Manag 102:823-837. https://doi.org/10.1016/j.wasman.2019.11.033

Cong R-G, Caro D, Thomsen M (2017) Is it beneficial to use biogas in the Danish transport sector? - An environmental-economic analysis. J Clean Prod 165:1025-1035. https://doi.org/10.1016/j.jclepro.2017.07.183

Cooper J, Hawkes A, Balcombe P (2019) Life cycle environmental impacts of natural gas drivetrains used in UK road freighting and impacts to UK emission targets. Science of The Total Environment 674:482493. https://doi.org/10.1016/j.scitotenv.2019.04.091

Costa G, Lieto A, Lombardi F (2019) LCA of a Consortium-Based MSW Management System to Quantify the Decrease in Environmental Impacts Achieved for Increasing Separate Collection Rates and Other Modifications. Sustainability 11:2810. https://doi.org/10.3390/su11102810

Dahlén L, Lagerkvist A (2010) Evaluation of recycling programmes in household waste collection systems. Waste Manag Res 28:577-586. https://doi.org/10.1177/0734242X09341193

Di Maria F, Micale C (2013) Impact of source segregation intensity of solid waste on fuel consumption and collection costs. Waste Manag 33:2170-2176. https://doi.org/10.1016/j.wasman.2013.06.023

EC-JRC - European Commission-Joint Research Centre (2010) International Reference Life Cycle Data System (ILCD) Handbook:general guide for life cycle assessment : detailed guidance. Publications Office, LU

EEA - European Environment Agency (2009) COPERT emission factors

ES - Espírito Santo (2019) State Plan for Solid Waste Management - Diagnosis on MSW management in Espírito Santo (Plano Estadual de Resíduos Sólidos - Diagnóstico sobre a gestão dos resíduos sólidos urbanos no Espírito Santo)

Farzaneh M, Zietsman J, Lee D-W (2009) Evaluation of In-Use Emissions from Refuse Trucks. Transp Res Rec 2123:38-45. https://doi.org/10.3141/2123-05

Ferronato N, Moresco L, Guisbert Lizarazu GE et al (2021) Sensitivity analysis and improvements of the recycling rate in municipal solid waste life cycle assessment: Focus on a Latin American developing 
context. Waste Manag 128:1-15. https://doi.org/10.1016/j.wasman.2021.04.043

Fontaras G, Martini G, Manfredi U et al (2012) Assessment of on-road emissions of four Euro V diesel and CNG waste collection trucks for supporting air-quality improvement initiatives in the city of Milan. Science of The Total Environment 426:65-72. https://doi.org/10.1016/j.scitotenv.2012.03.038

Gallardo A, Bovea MD, Colomer FJ, Prades M (2012) Analysis of collection systems for sorted household waste in Spain. Waste Manag 32:1623-1633. https://doi.org/10.1016/j.wasman.2012.04.006

Gentil EC, Damgaard A, Hauschild M et al (2010) Models for waste life cycle assessment: Review of technical assumptions. Waste Manag 30:2636-2648. https://doi.org/10.1016/j.wasman.2010.06.004

Gilardino A, Rojas J, Mattos H et al (2017) Combining operational research and Life Cycle Assessment to optimize municipal solid waste collection in a district in Lima (Peru). J Clean Prod 156:589-603. https://doi.org/10.1016/j.jclepro.2017.04.005

Gredmaier L, Riley K, Vaz F, Heaven S (2013) Seasonal Yield and Fuel Consumed for Domestic, Organic Waste Collections in Currently Operational Door-to-Door and Bring-Type Collection Systems. Waste Biomass Valor 4:683-693. https://doi.org/10.1007/s12649-012-9193-8

Hauschild MZ, Huijbregts MAJ (2015) Introducing life cycle impact assessment. In: Life cycle impact assessment. Springer, pp 1-16

Hesterberg TW, Lapin CA, Bunn WB (2008) A Comparison of Emissions from Vehicles Fueled with Diesel or Compressed Natural Gas. Environ Sci Technol 42:6437-6445. https://doi.org/10.1021/es071718i

IBGE - Instituto Brasileiro de Geografia e Estatística (Brazilian Institute of Geography and Statistics) (2010) Panorama. In: IBGE | Cidades | Espírito Santo | Panorama.

https://cidades.ibge.gov.br/brasil/es/panorama. Accessed 15 Jul 2020

IEA (2020) Outlook for biogas and biomethane. Paris

IPCC - Intergovernmental Panel on Climate Change (2014) Fifth Assessment Report - IPCC

ISO - International Organization for Standardization (2006a) ISO 14040:2006 - Environmental management. Life cycle assessment. Principles and framework.

https://www.iso.org/obp/ui/\#iso:std:iso:14040:ed-2:v1:en. Accessed 2 Jan 2021

ISO - International Organization for Standardization (2006b) ISO 14044:2006 - Environmental management. Life cycle assessment. Requirements and guidelines. https://www.iso.org/obp/ui/\#iso:std:iso:14044:ed-1:v1:en. Accessed 2 Jan 2021

Jaunich MK, Levis JW, DeCarolis JF et al (2016) Characterization of municipal solid waste collection operations. Resour Conserv Recycl 114:92-102. https://doi.org/10.1016/j.resconrec.2016.07.012 
Larsen AW, Vrgoc M, Christensen TH, Lieberknecht P (2009) Diesel consumption in waste collection and transport and its environmental significance. Waste Manag Res 27:652-659.

https://doi.org/10.1177/0734242X08097636

Laso J, García-Herrero I, Margallo M et al (2019) LCA-Based Comparison of Two Organic Fraction Municipal Solid Waste Collection Systems in Historical Centres in Spain. Energies 12:1407. https://doi.org/10.3390/en12071407

Laurent A, Bakas I, Clavreul J et al (2014) Review of LCA studies of solid waste management systems Part I: Lessons learned and perspectives. Waste Manag 34:573-588.

https://doi.org/10.1016/j.wasman.2013.10.045

Laurieri N, Lucchese A, Marino A, Digiesi S (2020) A Door-to-Door Waste Collection System Case Study: A Survey on its Sustainability and Effectiveness. Sustainability 12:5520.

https://doi.org/10.3390/su12145520

Lima P, de M, Olivo, Paulo F PL, et al (2019) Life Cycle Assessment of prospective MSW management based on integrated management planning in Campo Grande, Brazil. Waste Manag 90:59-71. https://doi.org/10.1016/j.wasman.2019.04.035

Lima PM, Colvero DA, Gomes APD et al (2018) Environmental assessment of existing and alternative options for management of municipal solid waste in Brazil. Waste Manag 78:857-870.

https://doi.org/10.1016/j.wasman.2018.07.007

López JM, Flores N, Jiménez F, Aparicio F (2009) Emissions Pollutant from Diesel, Biodiesel and Natural Gas Refuse Collection Vehicles in Urban Areas. In: Rauch S, Morrison GM, Monzón A (eds) Highway and Urban Environment. Springer Netherlands, Dordrecht, pp 141-148

Martinho G, Gomes A, Santos P et al (2017) A case study of packaging waste collection systems in Portugal - Part l: Performance and operation analysis. Waste Manag 61:96-107. https://doi.org/10.1016/j.wasman.2017.01.030

Milojevic S, Grocic D, Dragojlovic D (2016) CNG propulsion system for reducing noise of existing city buses. Istrazivanja i projektovanja za privredu 14:377-382. https://doi.org/10.5937/jaes14-10991

MMA - Ministério do Meio Ambiente (Brazilian Ministry of the Environment) (2012) National Plan for Solid Waste Management. Plano Nacional de Resíduos Sólidos)

MMA - Ministério do Meio Ambiente, Secretaria de Qualidade Ambiental (Brazilian Ministry of the Environment, Secretariat of Environmental Quality) (2020) National Plan for Solid Waste Management Public consultation (Plano Nacional de Resíduos Sólidos)

Møller J, Christensen TJ (2007) LCA af dagrenovationssystemet i syv nordsjællandske kommuner - LCA of the MSW management system in seven North Zealand municipalities. DTU - Danmarks Tekniske 
Nguyen TTT, Wilson BG (2010) Fuel consumption estimation for kerbside municipal solid waste (MSW) collection activities. Waste Manag Res 28:289-297. https://doi.org/10.1177/0734242X09337656

Nizami AS, Rehan M, Waqas M et al (2017) Waste biorefineries: Enabling circular economies in developing countries. Biores Technol 241:1101-1117. https://doi.org/10.1016/j.biortech.2017.05.097

Paes MX, de Medeiros GA, Mancini SD et al (2020) Municipal solid waste management: Integrated analysis of environmental and economic indicators based on life cycle assessment. J Clean Prod 254:119848. https://doi.org/10.1016/j.jclepro.2019.119848

Paolini V, Petracchini F, Segreto M et al (2018) Environmental impact of biogas: A short review of current knowledge. Journal of Environmental Science Health Part A 53:899-906.

https://doi.org/10.1080/10934529.2018.1459076

Pavlas M, Dvořáček J, Pitschke T, Peche R (2020) Biowaste Treatment and Waste-To-EnergyEnvironmental Benefits. Energies 13:1994. https://doi.org/10.3390/en13081994

Pérez J, Lumbreras J, Rodríguez E (2020) Life cycle assessment as a decision-making tool for the design of urban solid waste pre-collection and collection/transport systems. Resources. Conservation Recycling 161:104988. https://doi.org/10.1016/j.resconrec.2020.104988

Pérez J, Lumbreras J, Rodríguez E, Vedrenne M (2017) A methodology for estimating the carbon footprint of waste collection vehicles under different scenarios: Application to Madrid. Transportation Research Part D: Transport Environment 52:156-171. https://doi.org/10.1016/j.trd.2017.03.007

Pires A, Martinho G, Rodrigues S, Gomes MI (2019) Sustainable Solid Waste Collection and Management. Springer International Publishing, Cham

Pires A, Sargedas J, Miguel M et al (2017) A case study of packaging waste collection systems in Portugal - Part II: Environmental and economic analysis. Waste Manag 61:108-116. https://doi.org/10.1016/j.wasman.2016.11.032

Pop IN, Muntean O-L, Costin D (2017) Life cycle analysis in evaluation of household waste collection and transport in Cluj-Napoca, Romania. International Journal of the Bioflux Society 9:13

Rodrigues S, Martinho G, Pires A (2016) Waste collection systems. Part A: a taxonomy. J Clean Prod 113:374-387. https://doi.org/10.1016/j.jclepro.2015.09.143

Sandhu GS, Frey HC, Bartelt-Hunt S, Jones E (2014) In-use measurement of the activity, fuel use, and emissions of front-loader refuse trucks. Atmos Environ 92:557-565.

https://doi.org/10.1016/j.atmosenv.2014.04.036 
Sandhu GS, Frey HC, Bartelt-Hunt S, Jones E (2020) Real-world activity, fuel use, and emissions of heavyduty compressed natural gas refuse trucks. Science of The Total Environment 143323. https://doi.org/10.1016/j.scitotenv.2020.143323

SNIS - Sistema Nacional de Informações sobre Saneamento (2019a) Diagnóstico do manejo de Resíduos Sólidos Urbanos - 2018. In: Planos de Resíduos Sólidos. http://www.snis.gov.br/diagnostico-anualresiduos-solidos/diagnostico-do-manejo-de-residuos-solidos-urbanos-2018. Accessed 15 Jun 2021

SNIS - Sistema Nacional de Informações sobre Saneamento (2020) Diagnóstico do manejo de Resíduos Sólidos Urbanos - 2019. In: Planos de Resíduos Sólidos. http://www.snis.gov.br/diagnostico-anualresiduos-solidos/diagnostico-do-manejo-de-residuos-solidos-urbanos-2019. Accessed 15 Jun 2021

SNIS - Sistema Nacional de Informações sobre Saneamento (2019b) Diagnóstico do manejo de Resíduos Sólidos Urbanos - 2017 (re-published). In: Planos de Resíduos Sólidos.

http://www.snis.gov.br/diagnostico-anual-residuos-solidos/diagnostico-rs-2017. Accessed 15 Jun 2021

Teixeira CA, Russo M, Matos C, Bentes I (2014) Evaluation of operational, economic, and environmental performance of mixed and selective collection of municipal solid waste: Porto case study. Waste Manag Res 32:1210-1218. https://doi.org/10.1177/0734242X14554642

Thiruvengadam A, Carder DK, Krishnamurthy M, Gautam M (2010) Comparison of Regulated and Unregulated Exhaust Emissions From a Fleet of Multi-Fuel Solid Resource Collection Vehicles. In: ASME 2010 Internal Combustion Engine Division Fall Technical Conference. ASMEDC, San Antonio, Texas, USA, pp 139-147

Tsalis T, Amarantidou S, Calabró P et al (2018) Door-to-door recyclables collection programmes: Willingness to participate and influential factors with a case study in the city of Xanthi (Greece). Waste Manag Res 36:760-766. https://doi.org/10.1177/0734242X18764291

Winslow KM, Laux SJ, Townsend TG (2019) An economic and environmental assessment on landfill gas to vehicle fuel conversion for waste hauling operations. Resour Conserv Recycl 142:155-166. https://doi.org/10.1016/j.resconrec.2018.11.021

Yaman C, Anil I, Jaunich MK et al (2019) Investigation and modelling of greenhouse gas emissions resulting from waste collection and transport activities. Waste Manag Res 37:1282-1290. https://doi.org/10.1177/0734242X19882482

Yıldız-Geyhan E, Yılan G, Altun-Çiftçioğlu GA, Kadırgan MAN (2019) Environmental and social life cycle sustainability assessment of different packaging waste collection systems. Resour Conserv Recycl 143:119-132. https://doi.org/10.1016/j.resconrec.2018.12.028

Yoon S, Collins J, Thiruvengadam A et al (2013) Criteria pollutant and greenhouse gas emissions from CNG transit buses equipped with three-way catalysts compared to lean-burn engines and oxidation 
catalyst technologies. J Air Waste Manag Assoc 63:926-933.

https://doi.org/10.1080/10962247.2013.800170

Zabeo A, Bellio C, Pizzol L et al (2017) Carbon footprint of municipal solid waste collection in the treviso area (Italy). Environ Eng Manag J 16:1781-1787. https://doi.org/10.30638/eemj.2017.194

Zhang J, Qin Q, Li G, Tseng C-H (2021) Sustainable municipal waste management strategies through life cycle assessment method: A review. J Environ Manage 287:112238.

https://doi.org/10.1016/j.jenvman.2021.112238

\section{Figures}




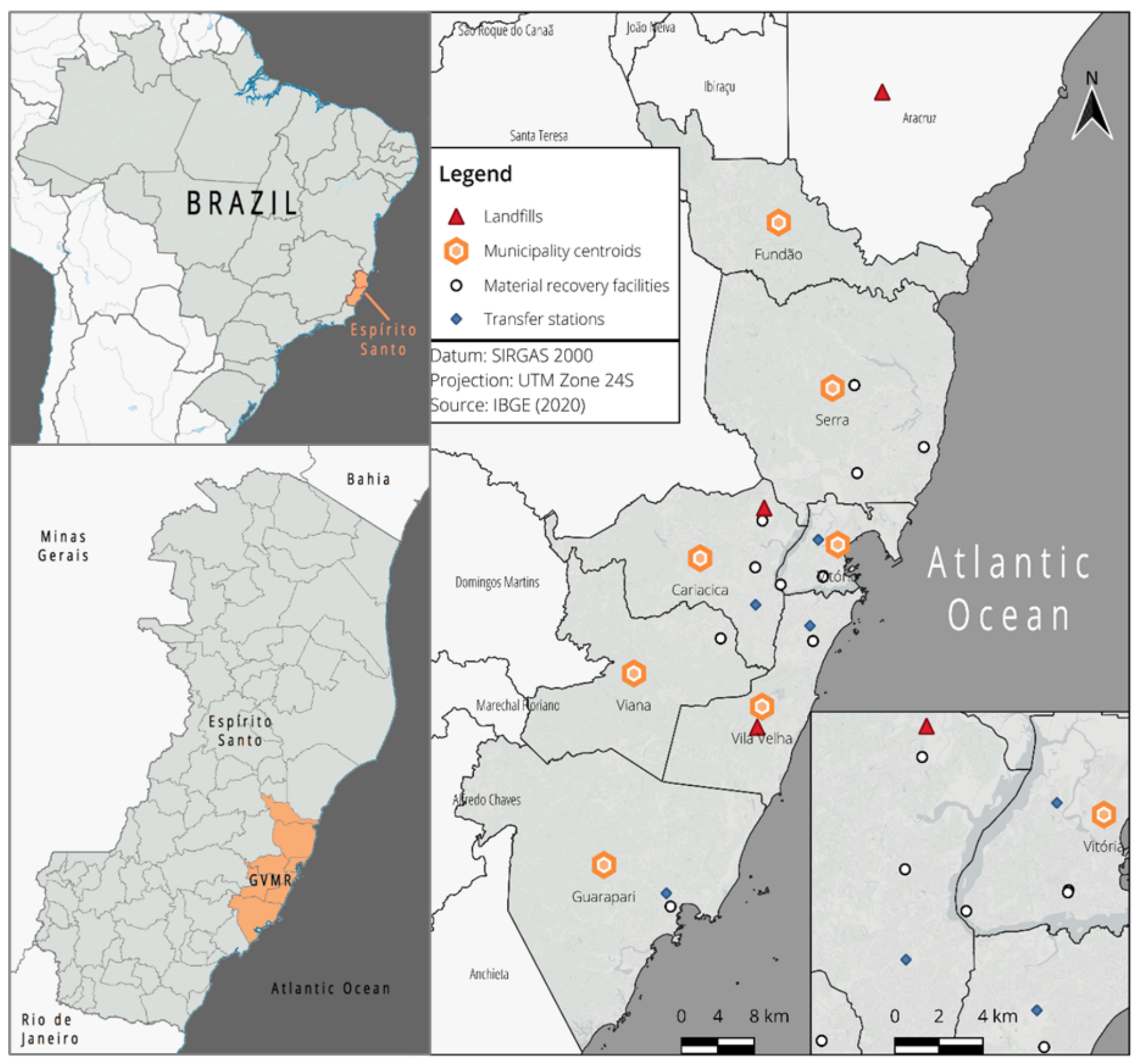

Figure 1

Great Vitória Metropolitan Region 


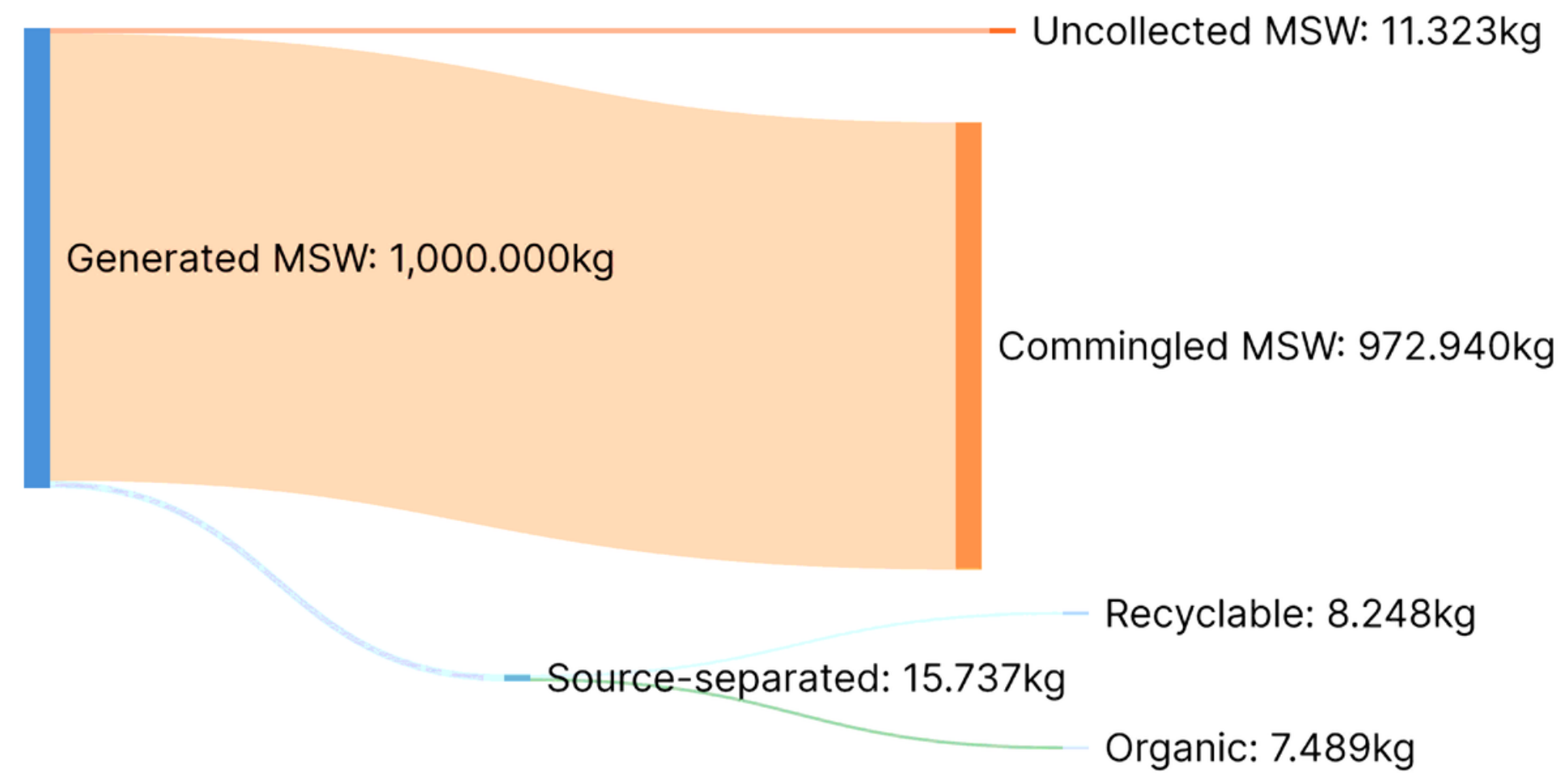

Figure 2

Sankey diagram of the MSW flow of the current management panorama in Great Vitória Metropolitan Region Source: (SNIS 2020, 2019b). 


\section{Separated Biowaste: $319.32 \mathrm{~kg}$}

Source-separated MSW: $600.02 \mathrm{~kg}$

Generated MSW: $1,000.00 \mathrm{~kg}$

Separated recyclables: $280.70 \mathrm{~kg}$

Commingled biowaste: $182.21 \mathrm{~kg}$

Commingled MSW: $399.98 \mathrm{~kg}$

Commingled recyclables: $137.66 \mathrm{~kg}$

Low Diversions (LD)

Non-recyclable refuse: $80.11 \mathrm{~kg}$

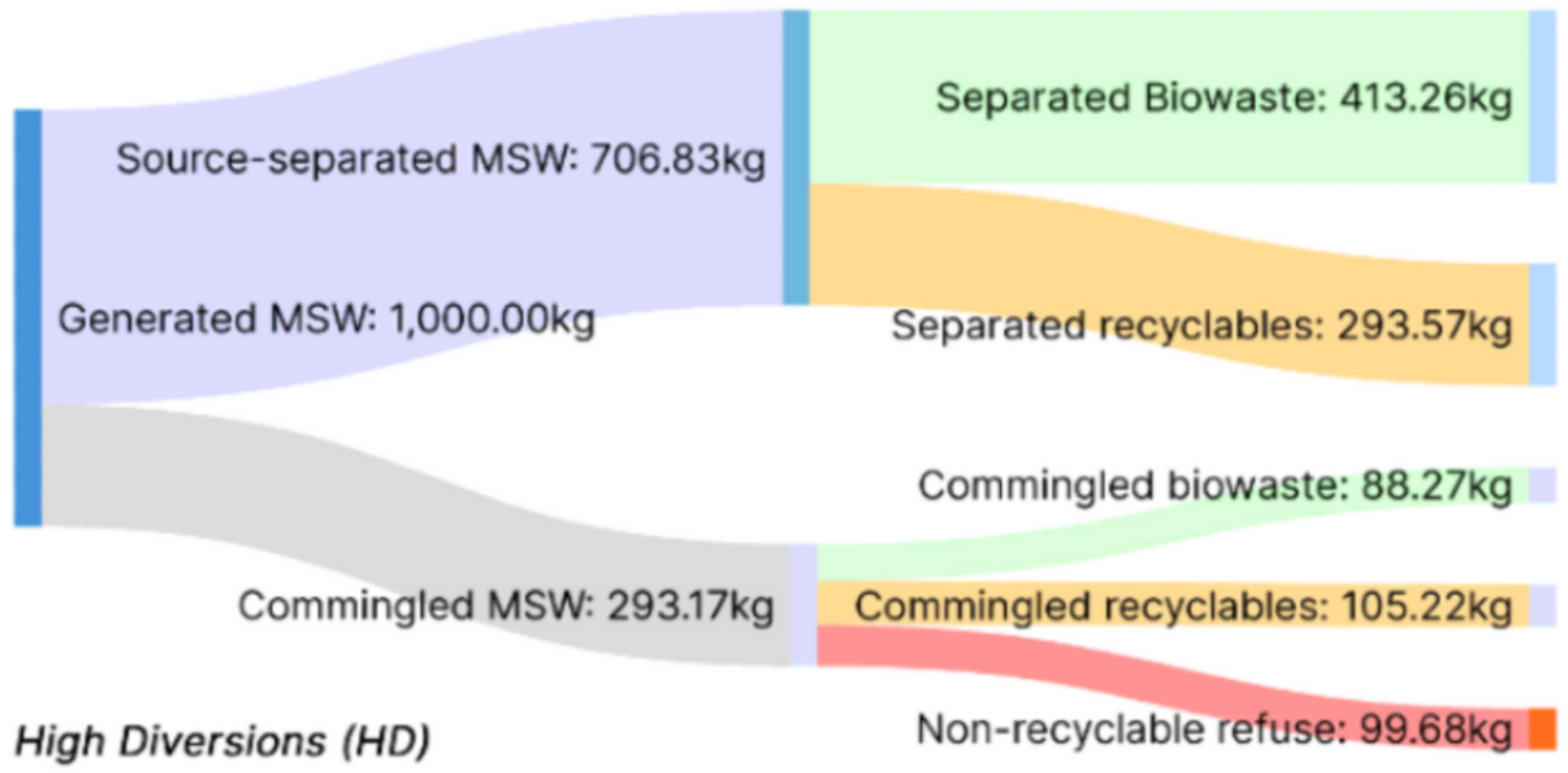

Figure 3

Sankey diagrams of the proposed low (LD) and high diversions (HD) scenarios 


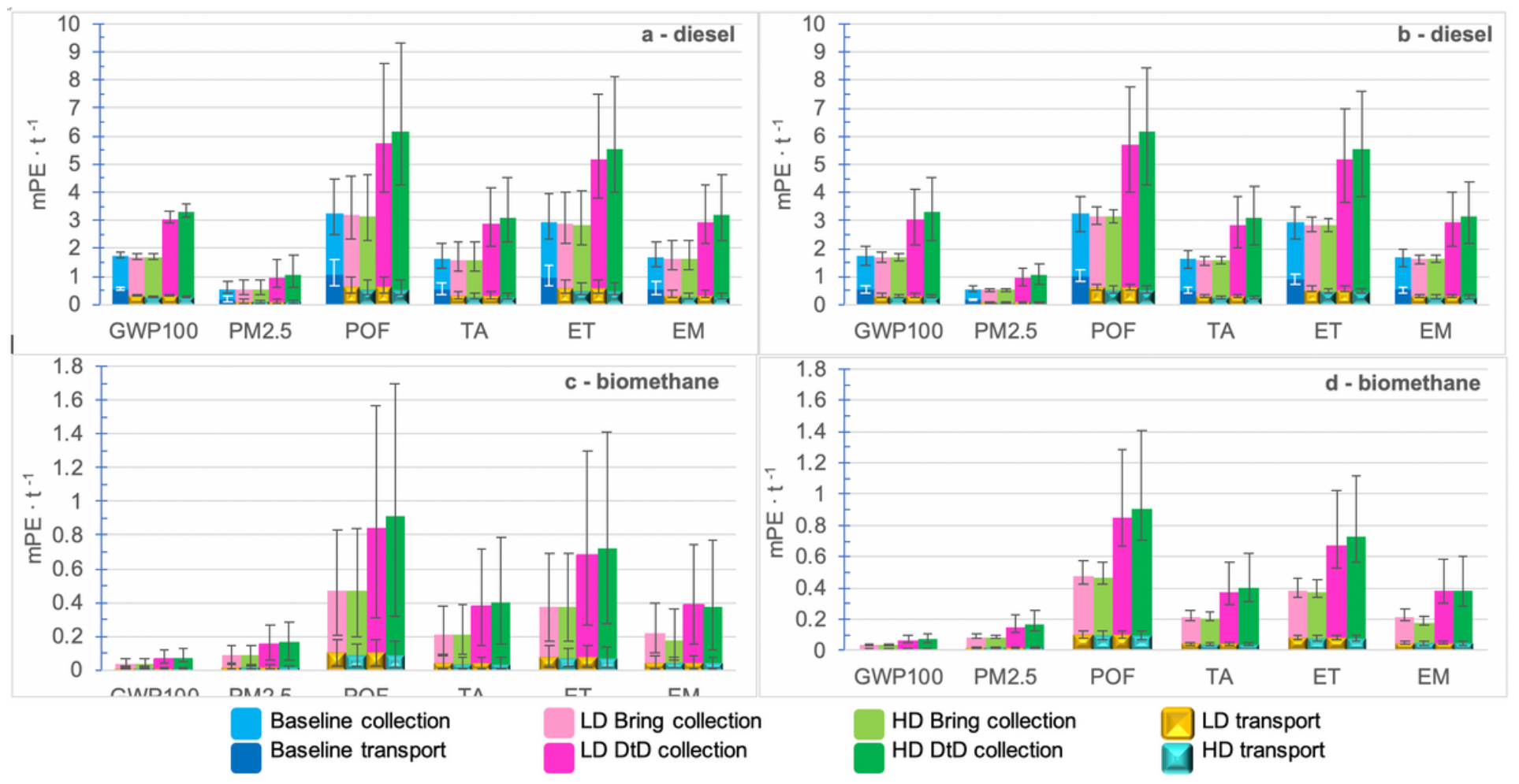

Figure 4

Normalized results with the respective errors for collection/transport using diesel and biomethane. A, C: values and errors calculated using extreme emission values; B, D: values and errors calculated using extreme fuel consumption values. (GWP100) Climate change, (PM2.5) Particulate Matter <2.5 $\mu \mathrm{m}$, (POF) Photochemical Ozone Formation, (TA) Terrestrial Acidification, (ET) Eutrophication Terrestrial, (EM) Eutrophication Marine. (LD) Low Diversions. (HD) High Diversions.

\section{Supplementary Files}

This is a list of supplementary files associated with this preprint. Click to download.

- Supplementarymaterial.docx 